\title{
Corporate Parents, Initial Legitimacy, and Resource Acquisition in Small and Medium Firms: An Empirical Examination
}

\author{
Gregory B. Murphy
}

Neil Tocher

\begin{abstract}
Omall and medium enterprises (SMEs) commonly
$\circlearrowleft$ struggle to acquire needed financial, buman, and technological resources. The above being stated, recent scholarly research argues that SMEs that are able to successfully navigate the legitimacy threshold are better able to gather the resources they need to survive and grow. This article provides an empirical test of that claim by examining whether the presence of a corporate parent positively influences SME resource acquisition. Results of the study show that SMEs with corporate parents, when compared to like-sized independent SMEs, have higher credit scores, have more complete management teams, use more computers, and are more likely to be on the Internet. These differences are most pronounced for very small firms and diminish in significance as firm size increases. Study implications include the notion that presence of a corporate parent likely represents a successful navigation of the legitimacy threshold, positively increasing SME resource acquisition.
\end{abstract}

Keywords: legitimacy threshold; parenting; new ventures; resource acquisition

Scholars argue that before a new venture is able to gather the resources it needs to survive and grow, it must first attain initial legitimacy from key stakeholders (Choi and Shepherd, 2005; Rutherford, Buller, and Stebbins, 2009). Thus, ventures that are not granted legitimacy by key stakeholders (i.e. stakeholders with the potential to provide significant and steady resources to the venture) will likely not be able to assemble needed resources such as financing, human capital, and technological assets, dramatically increasing their chances of failure (Aldrich and Martinez, 2001; Shepherd and Zacharakis, 2003). This study provides an empirical test of the above notion by examining whether SMEs with corporate parents are better able to gather resources (i.e. financing, managerial talent, technological assets) than SMEs without corporate parents.

\section{What Is Initial Legitimacy?}

Initial legitimacy is ". . . a social judgment of acceptance, appropriateness, and desirability, [that] enables organizations to access other resources needed to survive and grow" (Zimmerman and Zeitz, 2002). In this sense, key stakeholders-usually customers and financiers-grant initial legitimacy based on their assessment of both the entrepreneur and the emerging venture (Aldrich and Fiol, 1994; Choi and Shepherd, 2005). Once the stakeholder has determined that the venture is a legitimate operation, the stakeholder will typically signal such a decision by providing the venture with resources (Shepherd and Zacharakis, 2003). Once this signal has been sent by a key stakeholder, other stakeholders will realize that the venture is legitimate and will also provide resources, allowing the venture to survive and grow (Rutherford and Buller, 2007).

Attaining initial legitimacy is perhaps best described by the idea of a legitimacy threshold (LT), which Zimmerman and Zeitz (2002) define as "[the point] below which the new venture struggles for existence and probably will perish and above which the new venture can achieve further gains in legitimacy and resources." More specifically, researchers have observed that entrepreneurs tell fairly similar "made it" stories about the point at which entrepreneurs felt their firms had become commercially stable and were no longer engaged in a daily fight for survival (e.g. Rutherford and Buller, 2007; Zahra and Filatotchev, 2004). Such "made it stories" told by entrepreneurs typically involve the entrepreneur's firm being endorsed-or legitimized-by a resourceproviding stakeholder (e.g. Choi and Shepherd, 2005; Rutherford et al., 2009).

Why Should the LT be Empirically Examined? While the above indicates that emerging ventures likely experience the LT, few empirical studies have examined the relationship between successful navigation of the LT and small firm resource acquisition. In this article, we attempt to bridge this gap by examining if the presence of a corporate parent positively influences SME resource acquisition. In this sense, we view the presence of a corporate parent as a successful navigation of the LT and seek to understand if successful navigation of the LT does indeed allow ventures to attain needed resources.

Further, while there has been considerable debate in the strategy literature on the effectiveness of corporate parent- 
ing efforts (i.e., Chang and Singh, 2000; McGahan and Porter, 1997), such research has focused little attention on the effects parenting has on small subsidiary ventures (Brush and Bromily, 1997). Rather, parenting research has typically focused on the influence the practice has on the performance of large (often multinational) parent corporations. Hence, by assessing the possibility that the presence of a corporate parent positively influences SME resource acquisition, we contribute to the literature by providing an empirical examination of the above knowledge gap.

To accomplish the goals of our study, we first review research on the parenting effect, contrasting its influence to the resource scarcity commonly faced by SMEs due to the liability of smallness (LOS). Given such liabilities, we then explain the LT in detail, arguing that the presence of a corporate parent represents successful navigation of the LT and will thus positively influence SME resource acquisition. We use a comparison sample of 1,242 small subsidiaries and 2,099 independent small firms to test this notion before reporting results and discussing implications.

\section{The Parenting Effect}

Corporate strategy effects can be divided into two components: industry choice and corporate parenting. Industry choice refers to the idea that a firm may benefit from participating in industries that are more profitable than others. Parenting, the focus of this article, refers to the idea that subsidiary firms may benefit by having a corporate "parent" or owner. The primary benefit of corporate parenting is increased access to both resources and managerial guidance (Goold, Campbell, and Alexander, 1994).

The ability of corporate parenting to deliver increased firm performance has been widely debated in the strategy literature. Beginning with Schmalensee in 1985, scholars have argued about the amount of positive benefits that parenting provides (Wernerfelt and Montgomery, 1988; Rumelt, 1991; Brush and Bromily, 1997; McGahan and Porter, 1997; Chang and Singh, 2000). Specifically, Schmalensee (1985) found significant parenting effects while Rumelt (1991) found parenting effects to be trivial. Rumelt (1991) found "no evidence of non-zero corporate [parenting] effects" ( $p$. 178 ) in his first sample and a very small (2\%) parenting effect in his second sample. Subsequent research has found that parenting effects are stronger in the wholesale and retail sectors than in the manufacturing sector (McGahan and Porter, 1997) and that parenting effects are stronger when lines of business are defined more narrowly (Chang and Singh, 2000). However, even these studies have generally found a fairly modest corporate parenting/firm performance relationship for the larger firms they examined. McGahan and Porter (1997) found, for example, that "stable effects for corporate-parent membership account for only about 4 percent of the variance in business segment profit" (p. 24).

This line of research, however, has focused on large firms that have already overcome the LOS and the LT. Having successfully navigated the LT, the large subsidiary firms studied in the existing literature are better able to acquire needed resources on their own merits, reducing or eliminating the importance of the parent as a resource provider. By comparison, we would expect that parenting effects will be more significant for emerging ventures, particularly with regard to resource attainment. While larger subsidiaries may still benefit from a corporate parent's managerial guidance, smaller subsidiaries will likely benefit from both a parent's managerial guidance as well as the parent's ability to provide resources that the SME would not likely be able to acquire on its own.

Accordingly, while the literature as a whole suggests that corporate parenting has a modest positive influence on firm performance (e.g. Chang and Singh, 2000; McGahan and Porter, 1997; Schmalensee, 1985), we argue that parenting effects are likely to be more significant for emerging ventures that are still subject to the LOS and have likely not yet successfully navigated the LT. Given this, we next argue that the presence of a corporate parent suggests successful navigation of the LT and thus helps SMEs neutralize the LOS, which will in turn allow the subsidiary to better gather needed resources.

\section{Corporate Parenting and the LT}

In this article, we subscribe to the notion that most, if not all, SMEs must navigate a legitimacy threshold before they are able to acquire needed resources (Birley and Norburn, 1985; Zahra and Filatotchev, 2004). The central idea of the LT is that there exists a point in the early stage of most new ventures where the firm compiles some base level of legitimacy that enables it to survive and possibly grow (Zimmerman and Zeitz, 2002). Therefore, pre-legitimate ventures can be clearly contrasted with post-legitimate ventures in that they are just getting off the ground, financed entirely by seed money, have few (if any) substantial customers, and possess highly untenable resources; whereas post-legitimate ventures have acquired, or have access to, additional and more stable resources due to being granted at least a base level of legitimacy by a key stakeholder (Rutherford and Buller, 2007; Rutherford et al., 2009). Navigation of the LT is thus comparable to overcoming the LOS, which is a condition where emerging ventures possess limited power against market forces due to a lack of resources (Stinchcombe, 1965). More specifically, since emerging ventures commonly have limited debt capacity, poor cash flows, a limited product/service offering, and depend on niche markets, their survival and performance is more susceptible to market forces such as 
aggressive competitors, demand fluctuations, and powerful suppliers (Choi and Shepherd, 2005; Morris, 2001).

In this sense, navigating the legitimacy threshold is largely a resource issue (e.g., Pfeffer and Salancik, 1978), because pre-legitimate ventures usually possess only the founder's personal resources and what the founder has been able to raise from friends, family, and fools (Berger and Udell, 1998; 2006). Further, the pre-legitimate firm likely has few if any significant customers. Because of this resource deficiency, during the pre-legitimate stage, resource-providing stakeholders (i.e., financiers and customers) are usually the most important stakeholders from whom the firm must be granted legitimacy (Choi and Shepherd, 2005). Therefore, successful navigation of the LT is most commonly indicated by the provision of resources to the SME by a key stakeholder (Zimmerman and Zeitz, 2002; Zahra and Filatotchev, 2004). For example, post legitimacy may be indicated by events such as the SME landing its first major sale, entering a licensing agreement with a product distributor, or receiving financing from a business angel (Rutherford et al., 2009). While the above are all certainly viable, we assert that several lines of reasoning support the notion that SMEs with corporate parents have also successfully navigated the LT.

First, it is reasonable to assert that parent firms nearly always invest in legitimate ventures. As posited by Burgelman (1991) corporations have limited resources and thus managers will only invest such resources after much analysis. Hence, a parent/subsidiary relationship suggests that the parent has performed due diligence and concluded that the SME is legitimate (Lange, Boivie, and Henderson, 2009). Further, research in the large firm literature indicates that parents consistently provide subsidiary ventures with high levels of tangible resources (e.g. McKendrick and Carroll, 2001; McKendrick, et al., 2003; Stuart, Hoang, and Hybels, 1999), providing evidence that SMEs with corporate parents will have more consistent access to resources than independent SMEs. Finally, regardless of the amount of tangible resources that the SME acquires from the parent, the parent's presence will likely signal to other potential resource providers that the SME is more legitimate than comparable independent ventures (Aldrich and Martinez, 2001; Shepherd and Zacharakis, 2003). Thus, we conclude that the presence of a corporate parent represents a successful navigation of the LT and will thus enhance SME resource acquisition.

Given the above, we posit the following:

Hypothesis 1: Corporate parents will positively influence SME resource acquisition such that SMEs with corporate parents will gather more resources than SMEs without corporate parents.

\section{Corporate Parents and SME Resource Acquisition}

As acknowledged above, SMEs struggle to acquire needed resources, particularly in the areas of human capital (Hornsby and Kuratko, 2003), financing (Berger and Udell, 2006), and technological assets (Bernadas and Verville, 2005). Conversely, research on the LT provides evidence that SMEs which are granted legitimacy by a critical stakeholder will be better able to acquire needed resources (Rutherford and Buller, 2007; Zimmerman and Zeitz, 2002). Given that the presence of a corporate parent likely greatly increases SME legitimacy, we argue below that SMEs with corporate parents will have better access to technological, financial, and human resources than similar ventures that lack parents.

\section{Acquiring Financing}

It is well documented that new and small firms struggle to acquire needed financing and such struggles are a common cause of SME failure (e.g., Coleman, 2004; Gregory, Rutherford, Oswald, and Gardiner, 2005). Further, research also documents that to acquire financing; entrepreneurs often face additional constraints such as higher interest rates, weekly payments, and extensive personal guarantees (Barton and Matthews, 1989; Rutherford, Coombes, and Tocher, 2007). While SMEs struggle to raise capital for a variety of reasons, two primary causes are the fact that financiers often face severe information opacity with regard to the SME and the reality that SME financing is highly dependent on its founders' credit scores (Berger and Udell, 1998; 2006). More specifically, since the SME has few assets and often lacks the solid business reputation that creditors desire, the SME's credit score will either rely heavily or be entirely dependent upon its founders' credit scores (Brewer, 2007).

Therefore, we argue here that the presence of a corporate parent will help SMEs limit their information opacity and increase their credit score. For example, a parent will likely have a long and hopefully sound business record, which potential creditors will almost certainly reference when making loan decisions regarding the parent's subsidiaries (Lange et al., 2009; McKendrick, et al., 2003). In other words, while the SME may lack legitimacy and reputation, the parent will likely possess high levels of each, which a potential financier will most likely consider when deciding whether to provide financing to the parent's subsidiary. Such perceived legitimacy is presumed to positively influence the SME's ability to raise capital (Zimmerman and Zeitz, 2002). Further and perhaps more important, the presence of a parent will link the SME's credit score with the parent's credit score (Berger and Udell, 2006). Since it is almost certain that the parent's credit score will be higher and have more credence than the SME's credit score, a parent will likely positively influence 
SME access to capital. Given the above discussion, the following is advanced:

Hypothesis 2: The presence of a corporate parent will positively influence SME access to financing such that SMEs with a parent will have higher credit scores than comparable ventures without parents.

\section{Acquiring Managerial Talent}

The acquisition of a qualified management team is a complex issue for SMEs. On one hand, SMEs commonly struggle to attract and retain the qualified employees they desire, yet on the other hand, attracting and retaining competent employees is critically important to SME survival and performance (Cardon and Stevens, 2004; Tocher and Rutherford, 2009). Emphasizing the above statement, research indicates that managerial incompetence is one of the most common reasons for SME failure (Dun \& Bradstreet, 2001), yet emerging ventures typically place very little emphasis on formal HRM practices (Hornsby and Kuratko, 1990; 2003) and generally report not being able to attract competent employees (Williamson, 2000; Williamson, Cable, and Aldrich, 2002). Additional research indicates that SMEs (1) rely extensively on personal networks to find employees (e.g., Carroll, Marchington, Earnshaw, and Taylor, 1999), (2) use few if any formalized selection practices such as structured interviews, reference checks, or formal job applications (e.g., Kotey and Slade, 2005), and (3) often must compensate key employees at below market levels (Hayton, 2003). Further, due to factors such as a lack of training, limited promotion opportunities, and poor or absent supervision, SMEs often are unable to retain the few qualified employees they are able to attract (Tocher, Shook, and Giles, 2007).

While the above indicates that SMEs struggle to attract and select employees, research also suggests that the presence of a parent will likely help neutralize such challenges. For instance, the presence of a parent will significantly increase employer legitimacy (e.g., Williamson et al., 2002), positively influencing such factors as applicant pool quality, perceived promotion opportunity, and employee competence (Cardon and Stevens, 2004). Next, parent firms will almost certainly follow more formalized HRM practices than independent SME ventures (Kotey and Slade, 2005), and will probably require their subsidiaries to use similar practices. Using more formal HRM practices will likely result in more competent employees and better employee retention. Illustrating this point, research indicates that the use of formal HRM practices such as strict recruiting and selection practices, formal training programs, and employee empowerment initiatives tend to positively influence SME performance while decreasing turnover (e.g. Chandler and McEvoy, 2000; Hayton, 2003; Tocher and Rutherford, 2009). Finally, since parents tend to highly subsidize subsidiary ventures (McKendrick et al., 2003), it follows that such support will allow SMEs with parents to better compensate employees, neutralizing the pay gap often faced by SME ventures (Lange et al., 2009). Hence, the following is posited:

Hypothesis 3: The presence of a corporate parent will positively influence SME access to managerial talent such that SMEs with a parent will have more complete management teams than comparable ventures without parents.

\section{Acquiring Technology}

The acquisition and utilization of technology is also a doubleedged sword for SME ventures in that SMEs are often technological laggards (e.g. Bernadas and Verville, 2005), yet the use of technology is critical to establishing and maintaining the knowledge-based competitive advantages that are critically important in the global economy (Felin and Hesterly, 2007). SMEs often possess less technological assets than more established ventures for reasons such as a lack of capital to purchase technology (e.g. Robeiro and Love, 2003), fear that purchasing such items will hurt the firm's strategic flexibility (e.g. Murphy, Celuch, and Callaway, 2007), and a belief by SME managers that their ventures do not have enough competent employees to leverage the technology their firms already possess (e.g. Litz and Stewart, 2000). Given such concerns, SMEs often choose to either outsource certain technological functions or rely on strategic partnerships to accomplish such activities (Stam and Elfring, 2008).

Given the technological challenges often faced by SMEs, it seems that the presence of a corporate parent is a viable strategic partnering option for emerging firms attempting to leverage technological resources. Specifically, a parent will probably provide the SME the financing, competent employees, and training needed to acquire and use the latest technologies (McKendrick and Carroll, 2001; McKendrick et al., 2003). Similarly, a parent will likely allow its subsidiaries to access the technologies that the parent already possesses (Lange et al., 2009). Integrating the subsidiary's knowledge management systems into the parent's systems will usually benefit the subsidiary by providing it access to the parent's suppliers, customers, and partners (Lubit, 2001). Finally, the presence of a parent will help the subsidiary convince stakeholders such as customers and suppliers that any proprietary technologies it possesses are legitimate (Murphy and Smart, 2000).Supporting this notion, legitimacy scholars (e.g., Tornikoski and Newbert, 2007; Delmar and Shane, 2004) argue that communicating an association with a larger and better known organization such as a parent typically leads potential stakeholders to infer greater legitimacy on the proprietary resources of an emerging venture. Hence, we advance the following: 
Hypothesis 4: The presence of a corporate parent will positively influence SME utilization of technological resources such that SMEs with a parent will acquire and utilize more technological resources than comparable ventures without parents.

\section{Method}

Data for the study were gathered from Reference USA. Reference USA claims to report data on more than 14 million businesses in the United States. To identify a sample of small subsidiaries, data on nongovernment, nonbranch, and nonheadquarter subsidiary retail firms with less than 500 employees were gathered. A total of 1,242 such firms were identified. Retail firms were chosen because McGahan and Porter (1997) noted that corporate (parenting)-level effects are strongest in retail and wholesale industries. To identify a comparative sample, random names were chosen and used as street names to identify nongovernment, nonbranch, nonheadquarter, and nonsubsidiary, single location independent retail firms with less than 500 employees. This process identified 2,099 such firms. In general, subsidiary firms were larger than independent firms. Accordingly, tests for significant mean differences were conducted for the full sample as well as for each variable of interest by firm size (number of employees).

Credit numeric score was used to measure the firm's ability to access financial capital. Higher credit scores make it easier to attain working capital and debt financing on superior terms. Higher credit scores should also result in improved ability to access equity markets on superior terms. The confidence of financiers in a firm's ability to meet its financial obligations is reflected in a firm's credit score. This increased confidence should coincide with financiers' perceptions of reduced risk, thereby reducing the rate of return demanded by equity investors. Credit numeric scores in the samples range from 26 to 100.

Number of executives was used to measure the firm's ability to successfully recruit and retain important human resource talent. Reference USA lists up to 21 executives (including the primary firm contact) for each firm. Number of executives was measured as the total number of executives listed for each firm. The number of executives per firm ranged from 1 to 11 in the samples.

The presence of a website and the number of PCs were used as measures of technology use in this study. Reference USA lists the firm's URL if a website is available. Developing and maintaining a website can require extensive knowledge of computer-related technology, especially if the website has to be frequently updated and is used to take and place orders online. Firms with websites were coded with a 1 while firms without a website were coded with a 0 . Reference USA lists the number of PCs in a firm by category. Firms with 0-1 PCs were coded with 1; firms with 2-9 PCs, 2; firms with 10-29 PCs, 3; and firms with 30 or more PCs, 4. Reference USA does not report data on number of PCs for firms with 100 or more employees. Retailers use PCs for a variety of purposes such as inventory and customer database management. Increased use of PCs represents a commitment to using technology to perform functions that may otherwise be performed manually.

Subsidiary status was coded with a 1 if the firm had a corporate parent and with a 0 if the company was independently owned. Two control variables were included in the study. First, number of employees was included as a measure of firm size. Larger firms can be expected to have greater resources, making controlling for firm size important. Reference USA provides data on number of employees in size groupings: firms with 0-4 employees were coded 1; 5-9 employees, 2; 10-19 employees, 3; 20-49 employees, 4; 50-99 employees, 5; 100-249 employees, 6 ; and 250-499 employees, 7 . Firm age was the second control variable used. It is likely that older firms, like larger firms, have better access to resources, making controlling for firm age appropriate. The year the company first used a yellow page ad was used as a proxy for firm age. While an imperfect measure of firm age, retail firms have a strong interest in being listed in local yellow pages.

\begin{tabular}{|c|c|c|c|c|c|c|c|c|}
\hline & Mean & Std. & 1 & 2 & 3 & 4 & 5 & 6 \\
\hline 1.\# Employees & 3.62 & 1.90 & & & & & & \\
\hline 2. Firm Age & 1996.51 & 7.26 & $* *-.18$ & & & & & \\
\hline 3. Subsidiary & .37 & .48 & ***.23 & -.01 & & & & \\
\hline 4. Credit Score & 88.66 & 11.92 & $* * .47$ & $* * .40$ & **. 48 & & & \\
\hline 5.\# Executives & 2.13 & 1.93 & $* * .52$ & $* * .10$ & **..22 & ***.28 & & \\
\hline 6. Website & .36 & .48 & $* * .40$ & $*^{* *} .09$ & ***.27 & $* * 30$ & $* * 36$ & \\
\hline 7. \#PCs & 1.70 & .71 & $* * .67$ & $* *-12$ & $* * 37$ & $* * 39$ & $* * .40$ & **. 40 \\
\hline
\end{tabular}

${ }^{* *}=$ sig. at .01 


\section{Results}

Analysis proceeded in three stages. First, variable descriptive data and correlations are presented in Table 1 . Table 1 shows that the two control variables firm size and firm age are significantly correlated with most of the other variables in the study, indicating the appropriateness of their inclusion. The table also shows that subsidiary status is significantly and positively related to all of the variables of interest, suggesting that having a corporate parent leads to higher credit scores, a more complete management team, and better access to technology.

In the second stage, subsidiary status was regressed on credit score, number of executives, presence of a website, and the number of personal computers, using firm size and firm age as control variables. Table 2 shows the results of the two-step regressions. The results show that subsidiary status significantly improves the prediction of credit scores, number of executives, the likelihood of a website, and the number of personal computers employed, given controls for firm size and firm age. These results indicate that having a corporate parent significantly improves a small firms' ability to acquire important resources.

In the final stage of analysis, tests of significant mean differences between the subsidiary sample and the independent firms sample were conducted. Differences are tested for the seven size groupings ranging from $0-4$ employees to 250-499 employees. Table 3 reports the results of the analysis. These results are offered to more fully illustrate the differences between small independent and small subsidiary firms in their ability to acquire important resources, and to assess the extent that the legitimacy benefits of having a corporate

\begin{tabular}{|c|c|c|c|c|}
\hline \multicolumn{5}{|c|}{$\begin{array}{c}\text { Table 2. Regression of Subsidiary Status on Credit } \\
\text { Scores, Number of Executives, Presence of a Website, } \\
\text { and Number of Personal Computers }\end{array}$} \\
\hline & $\begin{array}{l}\text { Credit } \\
\text { Score }\end{array}$ & \# Executives & Website & \# PCs \\
\hline \multicolumn{5}{|l|}{ Stage 1} \\
\hline $\begin{array}{l}\text { Number of } \\
\text { Employees }\end{array}$ & $* * * .41$ & $* * * .52$ & $* * * .40$ & $* * * .68$ \\
\hline Firm Age & $* * * * .34$ & -.01 & -.02 & .01 \\
\hline \multicolumn{5}{|l|}{ Stage 2} \\
\hline $\begin{array}{l}\text { Subsidiary } \\
\text { Status }\end{array}$ & $* * * .40$ & $* * * .09$ & *****. 18 & $* * * .17$ \\
\hline $\mathrm{F}$ & *****1040.47 & $* * * 432.49$ & $* * * 259.52$ & $* * * 783.33$ \\
\hline Adjusted $\mathrm{R}^{2}$ & .48 & .28 & .19 & .48 \\
\hline $\begin{array}{l}\text { Significant } \\
\text { Change in } \mathrm{R}^{2}\end{array}$ & $* * * .16$ & $* * * .01$ & ****. 03 & $* * * .03$ \\
\hline
\end{tabular}

$* * * *$ sig. at .001

Standardized regression coefficients reported

$\mathrm{F}$ and Adjusted $\mathrm{R}^{2}$ are for Stage 2 Models parent are more pronounced for smaller firms.

Table 3 reveals frequent and consistent differences in resource levels between the subsidiary and independent firms. Regarding credit scores, subsidiary firms had higher credit scores than independent firms in the total sample as well as every size group. The greatest differences were found for smaller firms. Subsidiary firms with 0-4 employees had credit scores 20.24 points higher, on average, than comparably sized independent firms. By comparison, subsidiary firms with 100-249 employees had credit scores only 4.03 points higher, on average, than same-sized independent firms. Regarding number of executives, subsidiary firms employed more executives than independent firms in the total sample and in each size group except the largest group of firms with 250-499 employees. The most significant difference was again found in the smallest subsamples of firms with 0-4 employees. Regarding technology availability, subsidiary firms were much more likely to have a website than independent firms for the sample overall and for each size group except the largest group of firms with 250-499 employees. Here again, the greatest differences were observed for smaller firms. Subsidiaries with 0-4 employees were 9 times as likely as independent firms to have a website while subsidiaries with 5-9 and 10-19 employees were respectively almost 4 and 2 times more likely to have a website. Also, subsidiary firms used more PCs than independent firms for the overall sample and for each size group except the group with 5-9 employees.

Collectively, the results of the analyses provide strong support for the hypotheses. The general hypothesis (hypothesis 1) that SMEs with corporate parents will gather more resources than independent businesses was well supported by the data. The correlation data shows consistently greater resources for subsidiaries than independent firms. The regression analysis shows that this finding remains when controlling for firm size and firm age. Hypothesis 2, that small subsidiaries will have higher credit scores than independent small businesses is also strongly supported by the data. Table 2 shows a large (.16) and significant improvement in percentage of variance explained in credit scores as a result of including subsidiary status in the regression. Hypothesis 3, that small subsidiaries will have more complete management teams than independent small businesses, was also strongly supported by the data. Firm size, as measured by number of employees, was revealed in Table 2 to be the more significant control variable (firm age was not a significant predictor when firm size was included in the model). Table 3 revealed that subsidiary firms had more complete management teams than independent firms for the overall sample, as well as for every size subsample except the largest with 250-499 employees. Hypothesis 4, that small subsidiaries will make greater use of technology than independent small business- 
es, was also strongly supported by the data. These variables, like number of executives, were strongly influenced by firm size (and not firm age) as a control variable. Again, Table 3

\begin{tabular}{|c|c|c|c|}
\hline \multicolumn{4}{|c|}{$\begin{array}{l}\text { Table 3. Mean Differences Between Small } \\
\text { Independent and Subsidiary Retail Firms }\end{array}$} \\
\hline & Independent & Subsidiary & $\boldsymbol{F}$ \\
\hline Total Sample & $\mathrm{N}=2099$ & $\mathrm{~N}=1242$ & \\
\hline Credit Score & 84.27 & 96.07 & $* * * 991.61$ \\
\hline Number of Executives & 1.80 & 2.67 & $* * * 164.66$ \\
\hline Presence of Website & .26 & .52 & $* * * 258.37$ \\
\hline Number of PCs & 1.50 & 2.06 & $* * * 415.88$ \\
\hline 0-4 Employees & $N=674$ & $\mathrm{~N}=82$ & \\
\hline Credit Score & 76.42 & 95.66 & $* * * 357.45$ \\
\hline Number of Executives & 1.00 & 1.21 & $* * * 57.70$ \\
\hline Presence of Website & .03 & .27 & $* * * 85.05$ \\
\hline Number of PCs & 1.06 & 1.18 & $* * * 18.20$ \\
\hline 5-9 Employees & $\mathrm{N}=\mathbf{2 0 3}$ & $\mathrm{N}=116$ & \\
\hline Credit Score & 79.69 & 95.05 & $* * * 181.60$ \\
\hline Number of Executives & 1.00 & 1.26 & ****18.54 \\
\hline Presence of Website & .07 & .27 & $* * * 23.90$ \\
\hline Number of PCs & 1.45 & 1.55 & 2.58 \\
\hline 10-19 Employees & $\mathrm{N}=170$ & $\mathrm{~N}=\mathbf{1 8 0}$ & \\
\hline Credit Score & 81.77 & 95.77 & $* * * 191.96$ \\
\hline Number of Executives & 1.08 & 1.37 & $* * 9.16$ \\
\hline Presence of Website & .24 & .47 & $* * * 21.60$ \\
\hline Number of PCs & 1.35 & 1.86 & $* * * 51.50$ \\
\hline 20-49 Employees & $\mathrm{N}=472$ & $\mathrm{~N}=\mathbf{3 1 8}$ & \\
\hline Credit Score & 89.33 & 96.85 & $* * * 158.90$ \\
\hline Number of Executives & 1.98 & 2.23 & $* * 7.64$ \\
\hline Presence of Website & .38 & .53 & $* * * 19.54$ \\
\hline Number of PCs & 2.05 & 2.29 & $* * * 48.40$ \\
\hline 50-99 Employees & $\mathrm{N}=121$ & $\mathbf{N}=217$ & \\
\hline Credit Score & 90.73 & 96.40 & $* * * 25.11$ \\
\hline Number of Executives & 2.51 & 3.12 & $* * 8.29$ \\
\hline Presence of Website & .49 & .67 & $* * * 11.48$ \\
\hline Number of PCs & 2.05 & 2.47 & $* * * 28.44$ \\
\hline 100-249 Employees & $\mathrm{N}=\mathbf{4 0 3}$ & $\mathbf{N}=\mathbf{2 3 5}$ & \\
\hline Credit Score & 91.88 & 95.91 & $* * * 28.08$ \\
\hline Number of Executives & 3.19 & 4.34 & $* * * 28.41$ \\
\hline Presence of Website & .49 & .59 & $* * 6.63$ \\
\hline Number of PCs & N/A & N/A & N/A \\
\hline 250-499 Employees & $N=56$ & $\mathrm{~N}=72$ & \\
\hline Credit Score & 91.73 & 97.10 & ****11.60 \\
\hline Number of Executives & 3.57 & 4.17 & 1.34 \\
\hline Presence of Website & .57 & .60 & .77 \\
\hline Number of PCs & N/A & N/A & N/A \\
\hline
\end{tabular}

$* *=$ sig. at $.01,{ }^{* * *}=$ sig. at .001 illustrates that subsidiary firms were much more likely to have a website and employ more personal computers in their firms than their independent counterparts.

These findings support the general hypothesis that the presence of a parent will positively influence SME resource acquisition. Such findings lend support to the argument that the presence of a parent represents a successful navigation of the LT. Further, findings that the smaller subsidiaries had considerably more resources than comparable independent ventures and such resource differences declined as firms became more established (see Table 3 ) provide support for the notion that parenting may be most beneficial for pre-legitimate ventures.

\section{Discussion}

The current study provides solid empirical support for the notion that the presence of a parent will positively influence resource acquisition in emerging ventures. Specifically, our findings indicate that small subsidiary ventures typically have better credit ratings, have more managers, have more personal computers, and are more likely to have a website than comparably sized independent ventures. It should also be noted that such resource differences are most pronounced in very small firms and become less pronounced as firms become more established. Such findings indicate that while all SMEs with parents tend to be able to gather more resources than comparable ventures, the access to resources benefit of parenting appears to be far greater for smaller ventures.

The above findings make several important contributions to the literature. First, our article extends research on corporate parenting by examining its influence on SMEs. As previously mentioned, most research on corporate parenting effects tends to examine large, well-established ventures and has typically concluded that parenting benefits are generally marginal for such firms (e.g. Chang and Singh, 2000; McGahan and Porter, 1997). For example, recent work by Lange et al. (2009) even found that subsidiaries of corporate parents have higher failure rates than independently owned ventures. However, it should be noted that since established ventures have much better access to resources, the main benefit of parenting for large subsidiary ventures is the provision of managerial oversight from the parent to the subsidiary (Goold et al., 1994). Conversely, considering that emerging ventures tend to lack both legitimacy and tangible resources (Williamson, 2000), a parent may provide emerging ventures with additional benefits such as increasing the SME's perceived legitimacy and access to resources. Interestingly, our data supports the above by finding both that SMEs with parents tend to gather more resources than independent firms, and that such resource differences were most pronounced for smaller firms. Such findings suggest that parenting pro- 
vides SMEs increased access to resources and this increased access is greatest for smaller firms. Therefore, parenting does appear to be more beneficial for emerging ventures.

Second, our article provides needed empirical evidence to support the legitimacy threshold (LT) concept. While recent work provides solid evidence that the LT exists and that successfully navigating the LT is critical to firm survival (Choi and Shepherd, 2005; Rutherford and Buller, 2007; Zimmerman and Zeitz, 2002), empirical studies demonstrating critical differences between comparable pre-legitimate and post-legitimate firms are rare (Rutherford et al., 2009; Zahra and Filatotchev, 2004). Hence, by demonstrating that SMEs that have successfully crossed the LT by bringing on a corporate parent are better able to gather resources than comparable ventures, we provide additional empirical support for the LT concept and suggest that attracting a corporate parent is a viable option which may help entrepreneurs successfully navigate the LT.

Third, our study suggests that bringing on a corporate parent will help entrepreneurs operating early-stage ventures avoid the risky strategy of prioritizing stakeholder concerns. Several studies (e.g. Danov, Smith, and Mitchell, 2003; Jawahar and McLauphlin, 2001; Tocher and Rutherford, 2009) conclude that entrepreneurs operating early-stage ventures typically prioritize stakeholder concerns, paying most (if not all) of their attention to the concerns of resource-providing stakeholders-usually customers and financiers. At the same time, such entrepreneurs pay little if any attention to the concerns of stakeholders such as employees, suppliers, and community officials. However, such a strategy has also been shown to be problematic as research indicates that firms who address stakeholder concerns in a symbiotic manner tend to experience high performance levels (e.g. Bosse, Phillips, and Harrison, 2009; Laplume, Sonpar, and Litz, 2008). For instance, research by Dyer and Singh (1998) found that firms that are able to develop symbiotic relationships among various stakeholder groups typically experience higher performance levels than comparable firms who use primarily a zero sum approach to stakeholder management. Jawahar and Mclaughlin's (2001) argument for stakeholder prioritization is primarily based on the notion that emerging ventures must gather resources before all stakeholder interests can be aligned. However, if the presence of a parent allows emerging firms to gather needed resources, it seems that subsidiaries will be able to align stakeholder interests earlier in the venture's existence and avoid the risky stakeholder prioritization strategy.

Finally, in spite of the benefits of parenting discussed above, our results also suggest that entrepreneurs need to be aware of the LT when deciding to enter into a parenting subsidiary relationship. While parents typically increase emerging ventures' perceived legitimacy and access to resources, it can be assumed that ventures which have crossed the LT are seen as legitimate and are thus able to gather resources with or without the help of a parent (Aldrich and Martinez, 2001; Shepherd and Zacharakis, 2003). Therefore, similar to large established firms, the primary benefit that post-legitimate ventures will receive from parents is managerial guidance (Goold et al., 1994). Given the mixed results of research examining the parenting/firm performance relationship (e.g. Chang and Singh, 2000), an entrepreneur operating a postlegitimate venture should be very cautious when making the decision to enter into a parenting subsidiary relationship. If the entrepreneur believes that the firm could benefit substantially from the increased managerial guidance of a parent, she should consider the subsidiary option. However, if the entrepreneur believes that her management team can effectively guide the venture, she should think twice about bringing a parent on board.

\section{Limitations and Future Research}

This study, like any, has limitations. One limitation of this study was the unavailability of performance data. While our results do show that small subsidiaries have better access to important resources than independent small businesses, this study is not able to determine if improved access to resources, in this case, results in performance improvements for parents or their subsidiaries. Future research should consider the relationship between emerging venture legitimization by a parent and emerging firm performance. Specifically, do SMEs who are legitimized by corporate parents experience higher performance levels than comparably sized independent firms? On one hand, it seems that both the increased access to resources and the managerial oversight provided by the parent would allow the subsidiary to perform at a higher level. However, recent empirical research by Lange et al. (2009) actually indicates that corporate subsidiaries experience higher failure rates than comparable ventures. Given such findings, future research needs to examine whether subsidiaries do indeed perform at lower levels. Conversely, could it be that subsidiary ventures are more likely to fail because parents have unrealistic expectations and tend to pull resources from subsidiaries before they are able to fully develop their product/service offerings?

On a related note, it would be interesting to examine if parental managerial oversight creates a reality where subsidiary ventures are not as diversified as comparably sized independent firms. It is certainly possible that the corporate parent may prefer that the subsidiary focus their efforts narrowly, especially if the subsidiary is a supplier or distributor of the parent's products or services. Studies indicating that independent ventures that are more diversified tend to perform at higher levels than subsidiaries that are only allowed to carry a narrow product line may provide some explana- 
tion for Lange et al.'s (2009) somewhat contrary findings. Next, research should examine if performance levels vary for SME subsidiaries across the LT. In other words, do pre-legitimate SMEs that become subsidiaries experience better survival rates and higher performance levels than post-legitimate SMEs who become subsidiaries after crossing the LT? Research indicating that SMEs that used the legitimization of a parent to navigate the LT perform at higher levels than SMEs that became affiliated with parents after crossing the LT would provide additional credence to the claim that entrepreneurs operating post-legitimate ventures should be cautious about entering into a parenting subsidiary relationship.

Further, it is important to note that our study suggests a strategy for emerging firms (i.e. courting the support of a parent) that will likely lead to reduced independence for entrepreneurs. As many entrepreneurs value independence, an indepth study of entrepreneurs' personal experiences with becoming and being a subsidiary may help inform other entrepreneurs as to their potential satisfaction with such an arrangement.

Finally, this study was rough-grained in its approach. Future research could adopt a more fine-grained approach and add insight into the legitimization process and to a variety of possible differences between subsidiary and independent firms. For example, future research might consider the extent that small subsidiaries use their websites more to coordinate business activities, while small independent firms use their websites primarily to create firm awareness.

\section{Conclusion}

The current examination of resource acquisition benefits of corporate parenting in SMEs contributes to the literature by finding that parenting is highly beneficial for smaller, less established ventures. Using a comparison sample of 1,242 small subsidiaries and 2,099 independent small firms, we found strong evidence that the presence of a parent allows SMEs increased access to resources. Perhaps more importantly though, our findings also indicate that as firm size increases, resource differences between subsidiary and comparable independent ventures tend to steadily decrease, leading to the conclusion that parenting is likely much more beneficial for pre-legitimate ventures. Thus, it appears that the presence of a parent represents a successful navigation of the LT and supports the notion that since entrepreneurs operating subsidiary ventures will be able to access needed resources, they will be less likely to rely on the risky strategy of prioritizing stakeholder concerns. However, given previous research findings indicating that parenting's influence on performance is typically marginal (e.g. Chang and Singh, 2000), and possibly even negative (e.g. Lange et al., 2009), we submit that despite the increased resource access typically provided to SMEs by a parent firm, entrepreneurs operating post-legitimate ventures may not want to enter a parenting subsidiary relationship. Given that pre-legitimate ventures lack reputation and are typically in need of resources (Aldrich, 1999), our results suggest that pre-legitimate ventures should consider actively pursuing a parent. However, since post-legitimate ventures are likely able to access resources with or without the help of a parent, entrepreneurs operating post-legitimate ventures should only bring a parent on board if the entrepreneur is convinced that the parent's managerial oversight will increase her firm's performance.

\section{References}

Aldrich, H. E. (1999). Organizations evolving. London Sage.

Aldrich, H. E., and Fiol, C. M. (1994). Fools rush in? The institutional context of industry creation. Academy of Management Review, 18 (4), 445-470.

Aldrich, H. E., and Martinez, M.A. (2001). Many are called, but few are chosen:An evolutionary perspective for the study of entrepreneurship. Entrepreneurship Theory and Practice, 25 (4), 41-56.

Barton, S. L., and Matthews, C. H. (1989). Small firm financing: Implications from a strategic management perspective. Journal of Small Business Management, January: 1-7.

Berger, A. N., and Udell, G. F. (2006). A more complete conceptual framework for SME finance. Journal of Banking and Finance, 30: 2945-2966.

Berger, A. N., and Udell, G. F. (1998). The economics of small business finance:The roles of private equity and debt markets in the financial growth cycle. Journal of Banking and Finance, 22: 613-673.

Bernadas, C., and Verville, J. (2005). Disparity of the infusion of e-business within SMEs: A global perspective. International Journal of Technology Management, 31 (1/2): 39-46.

Birley, S., and Norburn, D. (1985). Small vs. large companies:The entrepreneurial conundrum. Journal of Business Strategy, 6 (1): 81-87.

Bosse, D.A. Phillips, R.A., and Harrison, J. S (2009). Stakeholders, reciprocity, and firm performance. Strategic Management Journal, 30 (4) 447-465. 
Brewer, E. (2007). On lending to small firms. Journal of Small Business Management, 45 (1): 42-46.

Brush, T. H., and Bromily, P. (1997). What does a small corporate effect mean? A variance components simulation of corporate and business effects. Strategic Management Journal, 18 (10): 825-835.

Burgelman, R.A. (1991). Intraorganizational ecology of strategy making and organizational adaptation:Theory and field research. Organization Science, 2, 239-262.

Cardon, M. S., and Stevens, C. E. (2004). Managing human resources in small organizations: What do we know? Human Resource Management Review, 14 (3): 295-323.

Carroll, M., Marchington, M., Earnshaw, J., and Taylor, S. (1999). Recruitment in small firms: Process, methods and problems. Employee Relations, 21(3): 236-250.

Chandler, G. N., and McEvoy, G. M. (2000). Human resource management, TQM, and firm performance in small and mediumsize enterprises. Entrepreneurship Theory and Practice, 25 (3), 43-57.

Chang, S. J., and Singh, H. (2000). Corporate and industry effects on business unit competitive position. Strategic Management Journal, 21 (7): 739-752.

Choi, Y. R., and Shepherd, D. A. (2005). Stakeholder perceptions of age and other dimensions of newness. Journal of Management, 31 (4), 573-595.

Coleman, S. (2004). Access to debt capital for women and minority owned small firms: Does educational attainment have an impact? Journal of Developmental Entrepreneurship, 9 (2), 127-143.

Danov, M. A., Smith, J. B., and Mitchell, R. K. (2003). Relationship prioritization for technology commercialization. Journal of Marketing Theory and Practice, 11 (3), 59-70.

Delmar, F., and Shane, S. (2004). Legitimating first: Organizing activities and the survival of new ventures. Journal of Business Venturing, 19, 385-410.

Dun \& Bradstreet (2001). The business failure record. New York: Dun \& Bradstreet Corporation.

Dyer, J., and Singh, H. 1998. The relational view: Cooperative strategy and sources of interorganizational competitive advantage. Academy of Management Review, 23: 660- 679.

Felin, T., and Hesterly, W.S. (2007). The knowledge-based view, nested heterogeneity, and new value creation: Philosophical considerations on the locus of knowledge. Academy of Management Review, 32 (1): 195-218.

Goold, M., Campbell,A., and Alexander, M. (1994). How corporate parents add value to the stand-alone performance of their businesses. Business Strategy Review, 5 (4): 33-55.

Gartner,W. B. (1989). Some suggestions for research on entrepreneurial traits and characteristics. Entrepreneurship Theory and Practice, 14 (1), 27-37.

Gregory, B.T., Rutherford, M.W., Oswald, S., and Gardiner, L. (2005). An empirical investigation of the growth cycle theory of small firm financing. Journal of Small Business Management, 43 (4): 382-392.

Hayton, J. (2003). Strategic human capital management in SMEs:An empirical study of entrepreneurial performance. Human Resource Management, 42 (4), 375-393.

Hornsby, J. S., and Kuratko, D. F. (2003). Human resource management in U.S. small businesses:A replication and extension. Journal of Developmental Entrepreneurship, 8 (1): 73-92.

Hornsby, J. S., and Kuratko, D. F. (1990). Human resource management in small business: Critical issues for the 1990's. Journal of Small Business Management, 28 (3), 9-18.

Jawahar, I. M., and Mclaughlin, G. (2001). Toward a descriptive stakeholder theory: An organizational life cycle approach. Academy of Management Review, 26 (3), 397-415.

Kotey, B., and Slade, P. (2005). Formal human resource management practices in small growing firms. Journal of Small Business Management, 43(1), 16-40.

Lange, D., Boivie, S., and Henderson, A. D. (2009). The parenting paradox: How multibusiness diversifiers endorse disruptive technologies while their corporate children struggle. Academy of Management Journal, 59 (2), 179-198.

Laplume, A. O., Sonpar, K., and Litz, R.A. (2008). Stakeholder theory: Reviewing a theory that moves us. Journal of Management. 34 (6) 1152-1175. 
Litz, R.A., and Stewart,A. C. (2000). Research note:Trade name franchise membership as a human resource management strategy: Does buying group training deliver 'true value' for small retailers? Entrepreneurship Theory and Practice, 25(1), 125-137.

Lubit, R. (2001). Tacit knowledge and knowledge management:The keys to sustainable competitive advantage. Organizational Dynamics, 29 (4), 164-178.

McGahan,A. M., and Porter, M. E. (1997). How much does industry matter, really? Strategic Management Journal, 18 : 15-30.

McKendrick, D. G., and Carroll, G. R. (2001). On the genesis of organizational forms: Evidence from the market for disk arrays. Organization Science, 12, 661-682.

McKendrick, D. G., Jaffee, J., Carroll, G. R., and Khessina, O. M. (2003). In the bud? Disk array producers as a (possibly) emergent organizational form. Adminis-trative Science Quarterly, 48, 60-93.

Morris, M. H. (2001). The critical role of resources. Journal of Developmental Entrepreneurship, 6(2): 5-9.

Murphy, G. B., Celuch, K., and Callaway, S. K. 2007. Small business Internet use and strategic flexibility. Journal of Small Business Strategy, 18(1): 57-68.

Murphy, G. B., and Smart, D. (2000). New and small e-commerce ventures:The importance of legitimacy and trust. New England Journal of Entrepreneurship, 3 (1): 33-45.

Pfeffer, J., and Salancik, G. R. (1978). The external control of organizations: A resource dependence perspective. New York: Harper and Row.

Robeiro, F.L., and Love, P.E.D. (2003). Value creation through an e-business strategy: Implication for SMEs in construction. Construction Innovation, 3 (1): 3-14.

Rumelt, R. (1991). How much does industry matter? Strategic Management Journal, 12 (3): 167-185.

Rutherford, M. W., and Buller, P. F. (2007). Searching for the legitimacy threshold. Journal of Management Inquiry, 16 (1) March, 78-92.

Rutherford, M. W., Buller, P. F., and Stebbins, M. (2009). Ethical considerations of the legitimacy lie. Entrepreneurship Theory and Practice, 33 (4), 949-964.

Rutherford, M.W., Coombes, S. M.T., and Tocher, N.Are We Legitimate Yet? An Exploratory Examination of Financing Options in Young Firms. Presented at the 2007 Academy of Management, Philadelphia, PA.

Schmalensee, R. (1985). Do markets differ much? The American Economic Review, 75 (3), 341-351.

Shepherd, D.A., and Zacharakis,A. (2003). A new venture's cognitive legitimacy:An assessment by customers. Journal of Small Business Management, 41 (2) 148-167.

Stam, W., and Elfring,T. (2008). Entrepreneurial orientation and new venture performance:The moderating role of intra- and extraindustry social capital. Academy of Management Journal, 51 (1), 97-115.

Stinchcombe, A.L. (1965). Social structure and organizations. In J. G. March, ed., Handbook of organizations (pp: 142-193). Chicago, Rand McNally.

Stuart, T. E., Hoang, H., and Hybels, R. C. (1999). Interorganizational endorsements and the performance of en-trepreneurial ventures. Administrative Science Quarterly, 44, 315-349.

Tocher, N., and Rutherford, M.W. (2009). Perceived acute human resource management problems in small and medium firms: An empirical examination. Entrepreneurship Theory and Practice, 33 (2), 221-239.

Tocher, N., Shook, C. L., and Giles, W. F. (2007). Training in small firms: An analysis of when small firms should emphasize formal and informal training to maximize performance. Journal of Business and Entrepreneurship, 19 (1): 76-90.

Tornikoski, E.T., and Newbert, S. L. (2007). Exploring the determinants of organizational emergence: A legitimacy perspective. Journal of Business Venturing, 22 (2), 311-335.

Wernerfelt, B., and Montgomery, C.A. (1988). Tobin's q and the importance of focus in firm performance. The American Economic Review, 78 (1): 246-250.

Williamson, I. O. (2000). Employer legitimacy and recruitment success in small businesses. Entrepreneurship, Theory and Practice, 25(1): 27-42. 
Williamson, I. O., Cable, D. M., and Aldrich, H. E. (2002). Smaller but not necessarily weaker: How small businesses can overcome barriers to recruitment. In J.A. Katz and T. M. Welbourne, eds., Managing people in entrepreneurial organizations: Learning from the merger of entrepreneurship and human resource management (pp. 83-106). Greenwich, CT: JAI Press.

Zahra, S.A., and Filatotchev, I. (2004). Governance of the entrepreneurial threshold firm: A knowledge-based perspective. Journal of Management Studies, 41, (5), 13-25.

Zimmerman, M.A., and Zeitz, G.J. (2002). Beyond survival:Achieving new venture growth by building legitimacy. Academy of Management Review, 27(3): 414-431.

\section{About the Authors}

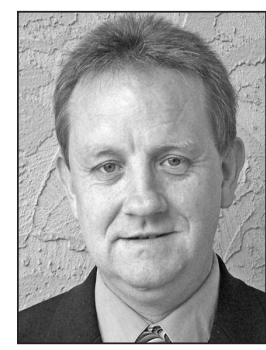

GrEGory MURPHY (murpgreg@isu.edu) is a professor of management at Idaho State University. He received his Ph.D. in business administration from the University of Houston. His research interests are in the areas of entrepreneurship, strategy, and electronic commerce. He has previously published in the Journal of Business Venturing, Journal of Business Research, Journal of High Technology Management Research, Journal of Business Economics Research, Journal of Small Business Strategy, Journal of Marketing Management, and New England Journal of Entrepreneurship.

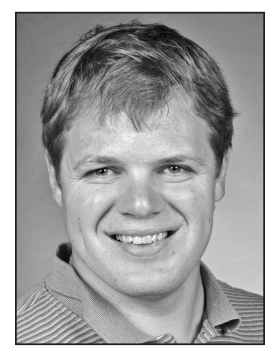

NeIL ToCHer (tochneil@isu.edu) is an assistant professor of management at Idaho State University. He received his doctorate in management from Auburn University in 2007. His primary research interests focus on the influence of human resource management practices on the performance of small and emerging firms. His research has appeared in the Journal of Business and Entrepreneurship, Journal of Employment Counseling, New England Journal of Entrepreneurship, and Entrepreneurship Theory and Practice. 